\title{
ISOLATION AND CHARACTERIZATION OF AMYLASE-PRODUCING MICROBES FROM THE DIGESTIVE TRACT OF TILAPIA
}

\author{
Sri Wahyuni ${ }^{1}$; Teguh Satria Amin ${ }^{2}$; Nomi Noviani ${ }^{3}$; Leni Handayani ${ }^{4}$ \\ ${ }^{1234}$ Universitas Muslim Nusantara Al Washliyah \\ ${ }^{1}$ sriwahyuni@umnaw.ac.id
}

\begin{abstract}
Enzymes are natural products that play an important role in various industrial applications, from food processing to chemical products. One of the many enzymes used is amylase. Amylase is an enzyme that plays a role in starch hydrolysis. One of the amylolytic bacteria can be isolated in the digestive tract of fish. This is because most bacteria that occupy the digestive tract have high activity. This study aims to obtain a potential isolate producing amylase bacteria whose activity can be determined through morphological characterization and activity test of enzyme-producing bacteria. The results obtained from this study were ten isolates with the potential to produce amylase enzymes, which were marked with a positive test after the addition of iodine.
\end{abstract}

Keywords: Enzymes, Amylase, Tilapia, Isolation.

\section{A. Introduction}

Indonesia has a biodiversity consisting of various types of plants, animals and microbes have potential in the production of enzymes. Enzymes are produced by all living things to catalyze biochemical reactions in the body of those living things so that those reactions can take place faster. Enzymes sourced from microorganisms in general are in high demand by industry because they have several advantages over other sources such as animals and plants. Today, enzymes are widely used for various commercial purposes in industry, agricultural, chemical and medical products because high efficiency can be produced from a variety of sources at a lower cost. Enzymes are one of the natural products that play an important role in various industrial applications, ranging from food processing to valuable chemical products.

Among the societies enzymes have traditionally been used since time immemorial, such as in cheese making, tanning and softening of meat. These properties cause the use 
of enzymes to increase from year to year, an increase estimated at $10-15 \%$ per year. One group of enzymes that has very important benefits in the industrial field is hydrolytic. The production and trade of enzymes is dominated by groups of hydrolytic enzymes such as amylase, protease, selulase, catalase and lipase. The presence of enzyme-producing microbes can be isolated from various sources, one of which is in the digestible tract of fish. Most bacteria that occupy the gastrointestinal tract have high activity in the absorption of nutrients, this is because there are digestive enzymes including amylase that are able to carry out carbohydrate metabolism activities into simpler sugars. In addition there are lipase enzymes that can change it in the form of fatty acids. The presence of these enzymes can meet the needs of fish in activities, grow and become an immune system for him.

\section{B. Method}

\section{Isolation of Microorganisms}

Isolation is carried out by a multilevel dilution method by means of as many as 5 sterile test tubes each filled with physiological $\mathrm{NaCl}$ as much as $9 \mathrm{ml}$, then the test tube is labeled dilution $10^{-1}, 10^{-2}, 10^{-3}$, and $10^{-4}$. The sample in the pipette is $1 \mathrm{ml}$ from each sample and then inserted into a dilution tube $10^{-1}$ and homogenized. Then from the dilution tube $10^{-1}$ is taken a sample of $1 \mathrm{~mL}$ and then inserted into a dilution tube $10^{-2}$. Dilution is carried out in stages up to $10^{-4}$. Samples of dilution results were further cultured on Nutrient Agar media containing starch stach incredated 24 hours at a temperature of $37^{\circ} \mathrm{C}$ to isolate amylase bacteria.

\section{Purification of microorganisms}

The results of the purification of the first stage culture, then carried out the second stage subculture in the medium Nutrient Agar (NA) by taking $1 \mathrm{ml}$ continued the spread plate method aseptis above the solid media Nutrient Agar (NA) as much as 3 times or until obtained pure colonies that are consistent and do not mix with other bacterial colonies. The inokulum is then incapacised at $37^{\circ} \mathrm{C}$ for 24 hours.

\section{Hydrolytic Activity Test}

The potency of amylase enzymes is done by means of pure bacterial colonies inoculated on the Agar Starch medium. Bacterial isolates are suspended in a physiological $\mathrm{NaCl}$ solution until the turbidity is equal to the turbidity of a 0.5 standard Mac Farland solution equivalent to $10^{8} \mathrm{CFU}$. From each bacterial suspension is taken $5 \mu$ suspension using micropipet, then dripped precisely in the middle of a petri dish that already 
contains starch agar media that is sterilized and then increditated for 24-48 hours at a temperature of $37^{\circ} \mathrm{C}$. Then, it is dripped a few drops of Gram's iodine as an indicator of the presence of glucose resulting from the process of hydrolysis of the substrate by the amylase enzyme from bacteria. A positive reaction is indicated by the formation of a clear zone in the overgrown part of the bacteria. This indicates that the bacterial isolate is able to produce amylase enzymes that can hydrolyze starch contained in the medium. While the fat hydrolysis test can be seen from the formation of clear zones around the media that contain lipids.

\section{Selection of Microorganisms}

a. Morphological observations

These identifications include shape, elevation, margin, size, consistency, color, properties. Microscopic observations are made, including cell morphology and color. Gram-positive bacteria will be purplish blue, while Gram-negative bacteria will be red (Waluyo, 2005).

\section{b. Gram Staining}

Gram staining is done to determine the morphology of the cell by 1 ose biakan sample dripped on the glass of the object, then annexed over the fire, dripped violet crystal staining and left for 1 minute, washed with running water. Then tested alcohol $96 \%$ and left for 10-20 seconds, washed with running water and added safranin left for 20-30 seconds, then washed again using absorbent paper and added immersion oil, then observed under a microscope. If the coloring is obtained by red bacteria, then the bacteria are gram negative bacteria, while if obtained purple bacteria then the bacteria are Gram positive bacteria (Fitri, et.al, 2011).

\section{Results and Discussions}

\section{Characterization of Microbial Morphology from Food and Beverage Samples} Isolation of amylase enzyme-producing microbes from the digestive tract of tilapia fish, obtained the following isolate characterization:

Table.1. Characterization of microbes in the fish's gastrointestinal tract

\begin{tabular}{|l|c|c|c|c|c|}
\hline Source Isolated & $\begin{array}{l}\text { Isolat } \\
\text { code }\end{array}$ & Shape & Edge & Elevation & Color \\
\hline $\begin{array}{l}\text { Gastrointestinal } \\
\text { Tract of Tilapia } \\
\text { Fish }\end{array}$ & AM 1 & Circular & Entire & Flat & Cream \\
\cline { 2 - 6 } & AM 2 & Irregular & Lobate & Flat & Cream \\
\cline { 2 - 6 } & AM 3 & Circular & Undulate & raised & Cream \\
\hline
\end{tabular}


Sri Wahyuni; Teguh Satria Amin; Nomi Noviani; Leni Handayani

\begin{tabular}{|c|c|c|c|c|c|}
\hline & AM 4 & Irregular & Undulate & Flat & White \\
\cline { 2 - 6 } & AM 5 & Irregular & Entire & Convex & Cream \\
\cline { 2 - 6 } & AM 6 & Circular & Lobate & Flat & White \\
\hline
\end{tabular}

From Table 1. It was obtained that the number of bacterial colonies contained in the medium containing starch (Starch Agar) amounted to Six Isolates. The presence of colonies of microbial samples isolated from the gastrointestinal tract suggests that microbes are able to grow on media with substrates containing starch. Microbes that grow in these media are able to hydrolyze starches and fats into simpler compounds.
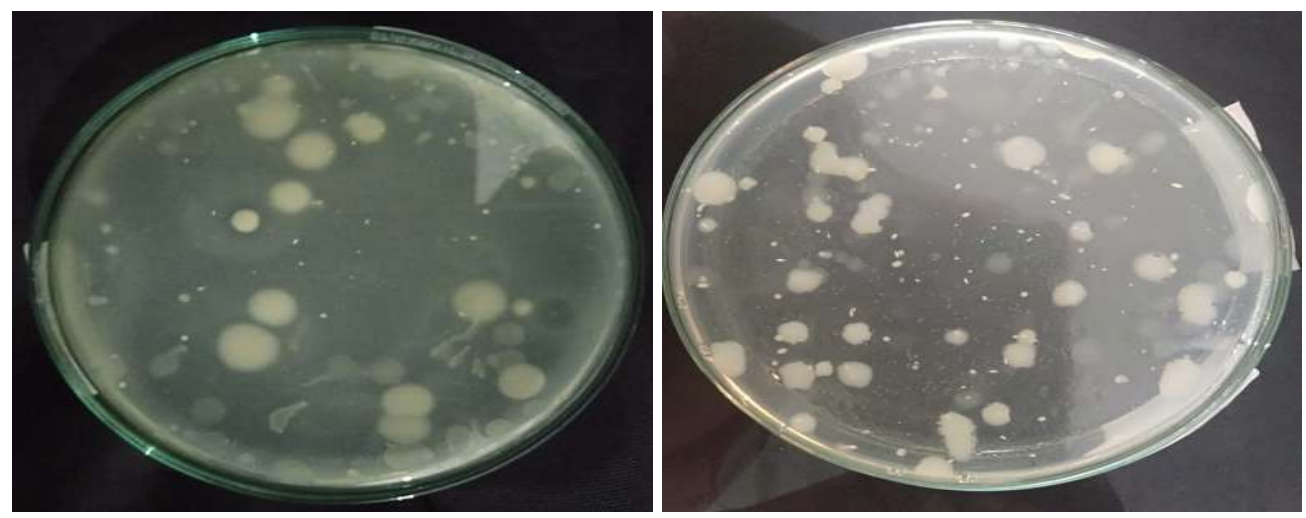

Figure 1. Microbial isolation results from the gastrointestinal tract

According to Singh et al. 2014, that the ability of microbes to grow on a medium indicates that the microbe can use substrates for their growth. The number of colonies in fish channels belongs to a large category. This can indicate that in the gastrointestinal tract there are many microbes that have many roles in the process of digestion of food.

According to Kurniasih, 2013. Showing that most bacteria that occupy the gastrointestinal tract have high activity in the absorption of nutrients, this is because there are digestive enzymes including amylase that are able to carry out carbohydrate metabolism activities into simpler sugars. In addition there are lipase enzymes that can change it in the form of fatty acids. The presence of these enzymes can meet the needs of fish in activities, grow and become an immune system for him. 


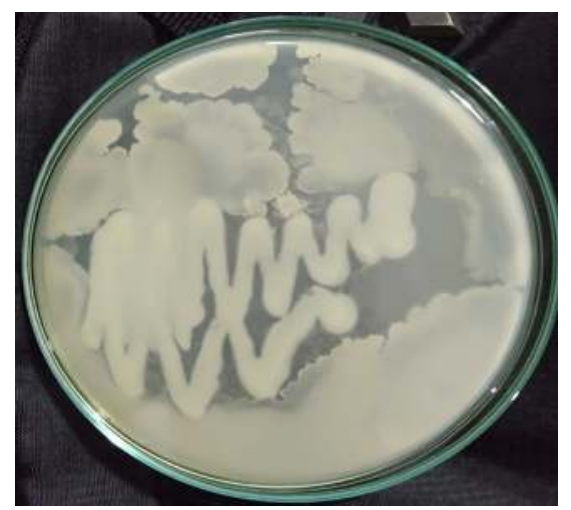

Figure 2. Amylase-producing potential isolate

From the results of the isolate obtained to see the activity of these microbes able to hydrolyze starch compounds can be done by dripping lodine Solution. Positive results of starch tests show around the colony experiencing degradation of starch so that the media around the colony is clear. As for seeing the activity of bacteria in the media containing fat seen around the colony there are oil components and bacteria look like glowing. From the results of isolated activity that has been characterized obtained data:

Table 2. Positive Results Isolated has amylase potential

\begin{tabular}{|c|c|}
\hline Isolat code & Amylase Test Results \\
\hline AM 1 & positive \\
\hline AM 2 & positive \\
\hline AM 3 & positive \\
\hline AM 4 & positive \\
\hline AM 5 & positive \\
\hline AM 6 & positive \\
\hline
\end{tabular}

From Table 2. It showed that microbes that had positive results had the ability to produce extracellular enzymes, amylase, which play a role in degrading the substats of starch and fat in the media into simpler compounds. According to Silaban 2018, positive results indicate the presence of an observable hydrolysis zone in the form of a clear zone at the time of iodine addition. The production of such colors indicates that iodine (in the form of ion 13) is trapped in a coil of beta amyloid molecules. Starch forces the iodine atom into a linear arrangement in the central groove of the amylose coil. The transfer of the charge between starch and iodine results in iodine properly absorbing visible light which gives it an intense blue color. When starch is broken down into smaller carbohydrate units due to the action of amylase, a blue-black color is not produced. 
Amyllytic bacteria are a type of bacteria that can produce amylase enzymes and are able to break down starch. The habitat of amyllytic bacteria can be fresh water such as lakes, rivers and ponds. The widely known genus of amyllytic bacteria is Bacillus, Bacterriods, Lactobacillus, Clostridium, Micrococcus, Thermus, and Actinomycetes (Reddy, Nimmagadda, \& Rao, 2003).

\section{Characterization of Microbes with Gram Staining}

Characterization of Microbes with Gram staining obtained the following data:

\begin{tabular}{|c|l|l|}
\hline No & \multicolumn{1}{|c|}{ Isolat code } & \multicolumn{1}{|c|}{ Gram Staining Results } \\
\hline 1. & AM1 & Gram Positive \\
\hline 2 & AM2 & Gram Positive \\
\hline 3 & AM3 & Gram Positive \\
\hline 4. & AM4 & Gram Positive \\
\hline 5. & AM5 & Gram Positive \\
\hline 6. & AM6 & Gram Positive \\
\hline 7. & AM7 & Gram Positive \\
\hline
\end{tabular}

From the results of gram staining obtained all isolates including gram positive, this shows that the color substance is able to be firmly attached to the bacterial cell wall by the entire isolate, thus showing a purple color. According to Fardiaz (1989), Gram positive and Gram negative bacteria are distinguished because of the cell wall's ability to bind to violet crystals. Gram positive bacteria are able to bind strongly violet crystals while gram negative bacteria are not able to bind strongly Violet crystals because the cell wall of the bacteria contains large amounts of lipids so that when decolorization with alcohol the pores enlarge and violet crystals dissolve in alcohol. Gram staining results showed that all isolate bacteria are purple and basil/stem shaped. According to De Vuyst \& Vandamme (Vuyst \& Vandamme, 1994), lactic acid bacteria in the form of basil/stem belong to the genus Lactobacillus, Bacillus.

\section{Conclusion}

From the results of the study it can be concluded that:

1. Of all the samples tested obtained the number of isolates there are 7 with different morphological character shapes based on visual observation results.

2. Based on amylase test activity obtained by bacteria that are classified as having extracellular enzymes, namely amylase enzymes, positive reactions obtained by the 
bacteria are able to degrade starch and fat media by showing clear colors around the colony.

3. Isolates that have been characterized based on the coloring carried out obtained results including gram positive groups with stem shape.

\section{Bibliography}

Qonita, S. B., Johan, V. S., \& Rahmayuni, R. (2018). Identifikasi Bakteri Asam Laktat dari Nira Aren Terfermentasi Spontan. Jurnal Online Mahasiswa Fakultas Pertanian, 5(1), 1-12.

Rahmiati, Pujianto, S., \& Kusdiyantini, E. (2016). Eksplorasi Mikroba Penghasil EnzimEnzim Hidrolitik di Kawasan Taman Nasional Lore Lindu Sulawesi Tengah. Jurnal Bioma: Berkala Ilmiah Biologi, 18(1), 14-19. doi:10.14710/bioma.18.2.14-19

Reddy, N., Nimmagadda, A., \& Rao, K. R. (2003). An Overview of the Microbial $\alpha$-Amylase Family. African Journal of Biotechnology, 2(12), 645-648. doi:10.5897/AJB2003.000-1119

Sunaryanto, R., \& Kaseno. (2004). Pemisahan Enzim Glukoamilase dari KalduFermentasi Menggunakan Membran Ultrafiltasi. Prosiding Seminar Nasional Rekayasa Kimia dan Proses, F(9), (9)1-5.

Syamsudin, Purwati, S., \& Rizaludin, A. T. (2008). Efektivitas Enzim dalam Sistem Lumpur Aktif Pada Pengolahan Air Limbah Pulp dan Kertas. Jurnal Selulola, 43(2), 83-92. doi:10.25269/jsel.v43i02.156

Tjahjaningsih, W., Masithah, E. D., Pramono, H., \& Suciati, P. (2016). Aktivitas Enzimatis Isolat Bakteri Asam Laktat Dari Saluran Pencernaan Kepiting Bakau (Scylla Spp.) Sebagai Kandidat Probiotik. Jurnal IImiah Perikanan dan Kelautan, 94-108. doi:10.20473/jipk.v8i2.11182

Vuyst, L. D., \& Vandamme, E. J. (1994). Antimicrobial Potential of Lactic Acid Bacteria. In Bacteriocins of Lactic Acid Bacteria (pp. 91-142). Springer, Boston, MA. doi:10.1007/978-1-4615-2668-1_3 